\title{
Surface components of Bacteroides fragilis involved in adhesion and haemagglutination
}

\author{
PETRA C. F. OYSTON and PAULINE S. HANDLEY \\ Microbiology Research Group, Department of Cell and Structural Biology, Stopford Building, University of Manchester, \\ Oxford Road, Manchester M13 9PT
}

\begin{abstract}
Summary. The ability of 19 strains of Bacteroides fragilis to adhere to buccal epithelial cells (BEC) and to the human intestinal cell line HT-29 Clone 19A, and to agglutinate rabbit erythrocytes was compared. Adhesion to BEC was poor compared with that to the cell line. Adhesion to the latter was high for $21 \%$ of the strains, moderate for $37 \%$ and poor for $42 \%$. Only $53 \%$ of the strains agglutinated rabbit red blood cells and only strain A459 did so strongly. Haemagglutination and adhesion of $B$. fragilis strain A459 were inhibited by sodium periodate, but not by proteases, heat or carbohydrates. These properties were not affected by protease which removed surface appendages. Periodate treatment did not remove the fimbriae or ruthenium red-staining layer, although the capsule was lost. This suggests that carbohydrate residues on the cell surface, possibly forming part of the capsule, are involved in adhesion and haemagglutination by this strain.
\end{abstract}

\section{Introduction}

Bacteroides fragilis is an important anaerobic pathogen that causes wound, intra-abdominal and urogenital infections and bacteraemia. ${ }^{1}$ The adhesive properties of $\boldsymbol{B}$. fragilis have been investigated by many workers because they may contribute to its pathogenicity, but the components responsible have not been unequivocably identified. The ability of $B$. fragilis to adhere to intestinal and buccal epithelial cells and to agglutinate erythrocytes has been studied extensively, ${ }^{2-8}$ but there is no agreement as to the identity of the surface components involved. Fimbriae, ${ }^{5}$ capsules ${ }^{2,9}$ and an electron-dense surface layer ${ }^{4}$ have all been implicated as adhesins.

Many enterobacterial haemagglutinins are blocked by specific carbohydrates ${ }^{10,11}$ but haemagglutination by $B$. fragilis is not inhibited by carbohydrates. $5,6,9$ However, it is inhibited by heat, periodate and some enzymes. ${ }^{6,7}$

We have compared the ability of 19 strains of $B$. fragilis to cause haemagglutination, as shown previously ${ }^{8}$ with their ability to adhere to an intestinal cell line and to buccal epithelial cells (BEC). The nature of the adhesins carried on one of these strains, A459, which is strongly adhesive and haemagglutinating, was investigated in detail.

\section{Materials and methods}

\section{Bacterial strains}

Bacteroides fragilis strains ATCC 23745 and NCTC 9343 were obtained from the National Collection of Type Cultures. The remaining 17 strains of $B$. fragilis had been isolated from abscesses: strain 2/79 was kindly provided by Dr H. Shah (London Hospital Medical College); strains MRI 2, MRI 3, MRI 6, MRI 7, MRI 8, MRI 9 and MRI 10 were isolated at the Manchester Royal Infirmary; strains A4, A200, A334, A363, A459, A312, SCI 7, SCI 9 and SCI 13 were kindly provided by Dr D. B. Drucker (University of Manchester).

Strains were identified as $B$. fragilis with the API 20A kit (AP/Laboratory Products, Basingstoke) for the identification of anaerobes.

\section{Media and growth conditions}

Cultures were grown in an anaerobic cabinet (Don Whitley Scientific, Shipley, W. Yorks; Mark II) at $37^{\circ} \mathrm{C}$ in an atmosphere of $\mathrm{N}_{2} 80 \%, \mathrm{H}_{2} 10 \%, \mathrm{CO}_{2}$ $10 \%$ v/v on Columbia Agar (Oxoid CM311) supplemented with horse blood $5 \% \mathrm{v} / \mathrm{v}$.

Organisms were grown in modified brain heart infusion (BHI) broth, $\mathrm{pH} 8$, containing (/L of distilled water): $\mathrm{BHI}$ powder (Oxoid CM225) $37 \mathrm{~g}$, yeast extract $5 \mathrm{~g}, \mathrm{NaHCO}_{3} 1 \mathrm{~g}, \mathrm{KNO}_{3} 1 \mathrm{~g}$, menadione $500 \mu \mathrm{g}$. 
Some strains were also grown in FUM medium prepared and sterilised as described by Loesche et al. ${ }^{12}$ FUM, $\mathrm{pH} 7 \cdot 1$, contained (/L of distilled water): tryptone $10 \mathrm{~g}$, yeast extract $5 \mathrm{~g}$, glucose $3 \mathrm{~g}$, haemin $2 \mathrm{mg}$, menadione $1 \mathrm{mg}$, cysteine hydrochloride $0.5 \mathrm{~g}$, $\mathrm{KH}_{2} \mathrm{PO}_{4} 0.45 \mathrm{~g}, \mathrm{~K}_{2} \mathrm{HPO}_{4} 0.45 \mathrm{~g},\left(\mathrm{NH}_{4}\right)_{2} \mathrm{SO}_{4} 0.9 \mathrm{~g}$, $\mathrm{MgSO}_{4} \cdot 7 \mathrm{H}_{2} \mathrm{O} 0 \cdot 188 \mathrm{~g}$.

\section{Haemagglutination studies}

Haemagglutination tests with rabbit erythrocytes were performed as described by Oyston and Handley. ${ }^{8}$ For inhibition studies, strain A459 was washed with PBS ( NaCl $8 \mathrm{~g} / \mathrm{L}, \mathrm{K}_{2} \mathrm{HPO}_{4} 1.21 \mathrm{~g} / \mathrm{L}, \mathrm{KH}_{2} \mathrm{PO}_{4} 0.34$ $\mathrm{g} / \mathrm{L}, \mathrm{pH} \mathrm{7.4)}$ and resuspended to an $\mathrm{OD}_{660}$ of $0 \cdot 1$ $\left(3 \times 10^{9}\right.$ bacteria/ml). The bacterial suspensions were treated with trypsin (Type III, Sigma) and protease from Streptomyces griseus (Type XIV, Sigma) at final enzyme concentrations of $2 \mathrm{mg} / \mathrm{ml}$ for up to $4 \mathrm{~h}$ at $37^{\circ} \mathrm{C}$; equal volumes of bacterial suspension and $\mathrm{NaIO}_{4}\left(100 \mathrm{~mm}\right.$ in water) were incubated at $37^{\circ} \mathrm{C}$ for up to $1 \mathrm{~h}$. After the above treatments bacteria were washed three times in PBS and resuspended to their original volume. Samples were also heated at $85^{\circ} \mathrm{C}$ for up to $1 \mathrm{~h}$. Mannose and fructose were included in the assay at a final concentration of $1 \mathrm{mg} / \mathrm{ml}$. The treated samples were then used for haemagglutination studies.

\section{Radiolabelling of bacteria}

Radiolabelled bacteria were prepared by inoculating $5 \mathrm{ml}$ of $\mathrm{FUM}$ containing $\mathrm{C}^{14}$ glucose $2 \mu \mathrm{Ci} / \mathrm{ml}$ from a Columbia blood plate. The cultures were incubated anaerobically for $24 \mathrm{~h}$ at $37^{\circ} \mathrm{C}$.

\section{Tissue culture}

The intestinal cell line HT-29 Clone $19 \mathrm{~A}^{13}$ was used with the kind permission of Dr C. Laboisse (Faculte de Medecine Xavier Bichat, Universite Paris VII) and supplied by Dr G. Warhurst (Clinical Pathology, Hope Hospital, Manchester). It was maintained in Nunc tissue-culture flasks in Dulbecco's Modification of Eagle's Medium (Flow Laboratories) with calf serum $10 \%$. The cells were subcultured weekly. When grown in Falcon tissue-culture plates, cell cultures were kept in a humidfied atmosphere containing $\mathrm{CO}_{2}$ $5 \%$ in air at $37^{\circ} \mathrm{C}$.

\section{Adhesion assay}

A modification of the assay of Vosbeck and Huber ${ }^{14}$ was used to assess the adherence of $B$. fragilis to intestinal epithelial cells. HT-29 tissue-culture monolayers were prepared in Falcon multiwell trays $\left(2 \mathrm{~cm}^{2}\right.$ wells) with an inoculum of trypsinised dissociated cells from a confluent culture. Confluent cell layers were washed twice with PBS immediately before use. PBS $(0.5 \mathrm{ml})$ was added to each well. Radiolabelled bacteria were washed three times with PBS and resuspended to $\mathrm{OD}_{550} 0.4\left(10^{9}\right.$ bacteria $\left./ \mathrm{ml}\right)$. To each of the monolayers was added $0.5 \mathrm{ml}$ of bacterial suspension. Four wells were used for each strain assayed. Trays were shaken on a plate shaker for $150 \mathrm{~min}$ at room temperature. Unbound bacteria were removed by washing the wells three times with PBS and the cells were lysed with $1.5 \mathrm{ml}$ of sodium dodecyl sulphate (SDS) $0.5 \% \mathrm{w} / \mathrm{v}$ overnight at room temperature. Samples $(0.5 \mathrm{ml})$ were transferred to Ecoscint A (Mensura Technology Ltd) and the amount of radioactivity was counted by liquid scintillation. The radioactivity bound in the assay was compared with the total count in the inoculum added to the monolayers to give a percentage adherence value. For comparison, a positive control, Escherichia coli MA 17 which adhered to the cell line, and a negative control, $E$. coli MA 8 which gave a very low level of adhesion, were included in the assay.

\section{Adhesion inhibition}

To ensure that the concentrations of the agents used in the treatments were comparable, with regard to bacterial number, with those used in the haemagglutination inhibition assays, bacterial suspensions of $\mathrm{OD}_{660} 1.0$ were used. However, to keep the adhesion assay conditions constant, suspensions of $\mathrm{OD}_{550} 0.4$ had to be used. Therefore, after treatment, the suspensions were washed and adjusted to $\mathrm{OD}_{550} 0 \cdot 4$. Since the heat- and carbohydrate-treated samples in the haemagglutination inhibition tests were not washed after treatment, suspensions of $\mathrm{OD}_{550} 0.4$ were used.

Radiolabelled cultures of $B$. fragilis A459 were washed three times with PBS and resuspended to $\mathrm{OD}_{550} 0.4$ or $\mathrm{OD}_{660} 1 \cdot 0$. The suspension of $\mathrm{OD}_{660} 1 \cdot 0$ was treated with trypsin, protease and periodate as described for haemagglutination inhibition. The bacteria were then washed three times in PBS and resuspended in buffer to a volume which would give $\mathrm{OD}_{550} 0.4$ for untreated cells. The other suspension $\left(\mathrm{OD}_{550} 0.4\right)$ was heated at $85^{\circ} \mathrm{C}$ or tested with the carbohydrates as described above. The treated samples were then assayed for adhesion. Differences between the adherence of treated and untreated suspensions were compared by Student's $t$ test.

\section{Effect of mucin on adhesion}

$\boldsymbol{B}$. fragilis A459 and monolayers were prepared and washed as for the adhesion assay. Monolayers were coated with $0.5 \mathrm{ml}$ of a solution of pig gastric mucin $(\mathrm{BDH})$ in distilled water $(58 \mathrm{~g} / \mathrm{L})$. Excess mucin was removed by gentle washing twice with PBS. The assay was then performed as described above.

\section{Buccal epithelial cell adherence assay}

Radiolabelled bacteria were washed with PBS, resuspended to $\mathrm{OD}_{550} 0.4\left(1 \times 10^{9}\right.$ bacteria $\left./ \mathrm{ml}\right)$ and 
mixed with BEC in PBS $\left(4 \times 10^{5}\right.$ cells $\left./ \mathrm{ml}\right)$. Bacterial adherence to $B E C$ was assayed by a modification of the method described by Harty et al. ${ }^{15}$ The radioactivity associated with the BEC was determined by scintillation counting, and the percentage adhesion was calculated as described by Handley et al. ${ }^{16}$ Streptococcus salivarius $\mathrm{HB}$ was included as a positive control strain with a high level of adhesion.

\section{Negative staining for fimbriae and fibrils}

The effect of trypsin, protease and $\mathrm{NaIO}_{4}$ on the fimbriae of strain A459 was shown by examining negatively stained preparations of the treated bacteria. Bacteria were washed three times with water and negatively stained as described by Handley and Tipler. ${ }^{17}$ A drop of bacterial suspension was placed on a carbon-coated grid ( 400 mesh, Agar Aids) which had been plasma-glowed in a Nanotech 300 S coating unit to produce a hydrophilic surface. The bacteria were then negatively stained with a drop of methylamine tungstate (Emscope) $2 \%$. Grids were examined with a Hitachi 600 electronmicroscope.

\section{Detection of capsules}

The effect of $\mathrm{NaIO}_{4}$ on the capsule of strain A459 was investigated. Capsules were detected by negative staining with Indian ink. One drop of a 24-h bacterial suspension was mixed on a microscope slide with a drop of glucose $10 \% \mathrm{w} / \mathrm{v}$ and a drop of Indian ink. This was spread thinly over the slide, allowed to dry in air, fixed with ethanol and stained with ammonium crystal violet. ${ }^{18}$

\section{Ruthenium red fixation}

After treatment of strain A459 with sodium periodate, cell surface located acidic polysaccharides were fixed with ruthenium red by the method described by Oyston and Handley. ${ }^{8}$ Sections were examined with a Hitachi 600 electronmicroscope.

\section{Results}

Adhesion to BEC was very low for all the $B$. fragilis strains tested-range $1 \cdot 6-4.8 \%$ of cells adhering. These values were low when compared with the positive control $S$. salivarius $\mathrm{HB}$ which was highly adherent in the BEC assay $(24.8 \%)$. In contrast, some strains adhered strongly to the intestinal epithelial cell line (table I). The most adherent strain in the tissue-culture assay was strain $\mathrm{A} 459(16.5 \%)$ and the least adherent was strain A363 (2.2\%). The positive control, E. coli MA 17, and the negative control, E. coli MA 8, gave values of $6 \cdot 3 \%$ and $0.4 \%$ respectively. Since a $2-\mathrm{cm}^{2}$ well contains $2 \times 10^{5}$ cells and the number of bacteria/ well is $5 \times 10^{8}, 16.5 \%$ adherence by strain A459 represents approximately 413 bacteria binding/intes-
Table I. Ability of $B$. fragilis to adhere to BEC and intestinal epithelial cells

\begin{tabular}{|c|c|c|c|c|}
\hline \multirow{2}{*}{$\begin{array}{c}\text { Strain } \\
\text { no. }\end{array}$} & \multirow{2}{*}{$\begin{array}{l}\text { Percentage of } \\
\text { cells with } \\
\text { fimbriae* }\end{array}$} & \multirow{2}{*}{$\underset{\text { titre* }}{\text { HA }}$} & \multicolumn{2}{|c|}{ Percentage adhesion to } \\
\hline & & & $\mathrm{BEC} \uparrow$ & HT-29‡ \\
\hline \multicolumn{5}{|l|}{ B. fragilis } \\
\hline A459 & 41 & $++t+$ & $3 \cdot 9(1 \cdot 4)$ & $16 \cdot 5(6 \cdot 8)$ \\
\hline A312 & 35 & + & $1 \cdot 6(0 \cdot 4)$ & $4 \cdot 7(0 \cdot 7)$ \\
\hline MRI 8 & 30 & - & $2 \cdot 7(0 \cdot 4)$ & $12 \cdot 2(3 \cdot 3)$ \\
\hline SCI 7 & 20 & - & $3 \cdot 7(0 \cdot 2)$ & $9 \cdot 0(2 \cdot 2)$ \\
\hline MRI 2 & 19 & $+t+$ & $2 \cdot 4(0 \cdot 8)$ & $3.9(0.9)$ \\
\hline MRI 10 & 16 & + & $3 \cdot 4(0 \cdot 4)$ & $9 \cdot 2(1 \cdot 1)$ \\
\hline $2 / 79$ & 14 & - & $2 \cdot 0(0 \cdot 3)$ & $6 \cdot 1(0 \cdot 6)$ \\
\hline MRI 9 & 11 & - & $4 \cdot 4(1 \cdot 0)$ & $4 \cdot 5(1 \cdot 4)$ \\
\hline MRI 7 & 11 & + & $1 \cdot 6(0 \cdot 3)$ & $8 \cdot 8(3 \cdot 5)$ \\
\hline A363 & 10 & - & $3 \cdot 5(0 \cdot 5)$ & $2 \cdot 2(0 \cdot 5)$ \\
\hline MRI 3 & 10 & - & $4 \cdot 8(0 \cdot 8)$ & $3 \cdot 8(1 \cdot 2)$ \\
\hline SCI 9 & 8 & - & $2 \cdot 7(0 \cdot 9)$ & $3 \cdot 8(1 \cdot 5)$ \\
\hline 9343 & 7 & - & $2 \cdot 9(1 \cdot 5)$ & $11 \cdot 2(1 \cdot 7)$ \\
\hline A200 & 7 & ++ & $2 \cdot 1(0 \cdot 2)$ & $5 \cdot 8(1 \cdot 1)$ \\
\hline MRI 6 & 6 & + & $3 \cdot 4(0 \cdot 5)$ & $8 \cdot 3(1 \cdot 5)$ \\
\hline A334 & 4 & + & $3 \cdot 2(0 \cdot 5)$ & $9 \cdot 6(1 \cdot 0)$ \\
\hline A4 & 0 & - & $3 \cdot 6(0 \cdot 7)$ & $2 \cdot 4(0 \cdot 6)$ \\
\hline SCI 13 & 0 & + & $2 \cdot 7(0 \cdot 4)$ & $12 \cdot 1(3 \cdot 7)$ \\
\hline 23745 & $12 \cdot 3 \S$ & + & $2 \cdot 4(0 \cdot 3)$ & $4 \cdot 9(2 \cdot 2)$ \\
\hline E. coli MA8 & $\ldots$ & $\ldots$ & ND & $6 \cdot 4(1 \cdot 1)$ \\
\hline E. coli MA17 & $\ldots$ & $\ldots$ & ND & $0.4(0.05)$ \\
\hline S. salivarius HB§ & $\ldots$ & $\ldots$ & $24 \cdot 8(3.6)$ & ND \\
\hline
\end{tabular}

ND, not done.

* See Oyston and Handley. ${ }^{8}$

$\dagger \mathrm{BEC}$ values are mean (SD) values from six replicates.

$\ddagger$ HT-29 adhesion values are mean (SD) values from two separate batches of monolayers, each with four replicates.

$\S$ Strain $23745^{1}$ and $S$. salivarius $\mathbf{H B}^{21}$ are fibrillate not fimbriate.

tinal cell. Strains can be divided into poorly adherent strains with less than 125 adhering bacteria/cell, moderately adherent strains with $125-250$ bacteria/ intestinal cell and highly adherent strains with more than 250 bacteria adhering/cell. By these criteria, 4 ( $21 \%)$ of 19 strains were highly adherent, $7(37 \%)$ were in the medium category and $8(42 \%)$ adhered in low numbers only. Coating the cell monolayer with mucins did not significantly decrease the adhesion of strain A459.

B. fragilis A459 was selected for further study of the surface components responsible for haemagglutination and adhesion. It was highly adherent in the HT29 assay, had the highest haemagglutination titre, and had a high proportion of fimbriate cells.

Pre-treatment with trypsin or protease, or carbohydrates, or heating to $85^{\circ} \mathrm{C}$ did not affect the ability of strain A459 to adhere to erythrocytes or the cell line. However, pre-treatment with sodium periodate for $45 \mathrm{~min}$ reduced adhesion in the tissue-culture assay by $50 \%$ and abolished haemagglutination after $1 \mathrm{~h}$ (table II).

Negative staining of the treated samples showed that the fimbriae of strain A 459 were partially removed by trypsin and totally removed by protease. Sodium periodate did not reduce the number of fimbriae. Indian ink films revealed that treatment for $1 \mathrm{~h}$ with periodate had removed the capsules from the majority 
Table II. Effect of treatments on haemagglutination and adhesion of B. fragilis A459

\begin{tabular}{lcc}
\hline \multicolumn{1}{c}{ Treatment } & HA titre & Adhesion score* $\%$ ) \\
\hline Control & 32 & 100 \\
Trypsin $2 \mathrm{mg} / \mathrm{ml}, 1 \mathrm{~h}$ & 32 & 100 \\
Protease $2 \mathrm{mg} / \mathrm{ml}, 1 \mathrm{~h}$ & 32 & 100 \\
$\mathrm{NaIO}_{4} 100 \mathrm{~mm}, 15 \mathrm{~min}$ & 8 & $\mathrm{ND}$ \\
$30 \mathrm{~min}$ & 4 & $\mathrm{ND}$ \\
$45 \mathrm{~min}$ & 2 & 50 \\
$60 \mathrm{~min}$ & 0 & 100 \\
Heat $85^{\circ} \mathrm{C}, 1 \mathrm{~h}$ & 32 & 100 \\
Mannose $1 \mathrm{mg} / \mathrm{ml}$ & 32 & 100 \\
Fructose $1 \mathrm{mg} / \mathrm{ml}$ & 32 &
\end{tabular}

ND, not done.

* Adhesion score relative to control (100\%).

of cells but subsequent ruthenium red staining did not reveal any reduction in the thickness of the ruthenium red staining layer (RRL). Since trypsin-treated and protease-treated cells did not lose their capsules, they were not stained with ruthenium red to detect any reduction in the thickness of the RRL. The results of the structural effects of the treatments on strain A459 are summarised in table III.

Table III. Effect of pre-treatments on the surface components of $B$. fragilis A459

\begin{tabular}{lccc}
\hline & \multicolumn{3}{c}{ Presence of } \\
\cline { 2 - 4 } \multicolumn{1}{c}{ Treatment } & $\begin{array}{c}\text { fimbriae* } \\
\text { (percentage } \\
\text { of cells) }\end{array}$ & capsule & $\begin{array}{c}\text { RRL } \\
\text { (width, nm) }\end{array}$ \\
\hline Control & 41 & + & 7.9 \\
Trypsin 2 mg/ml, 1 h & $27 \S$ & + & ND \\
Protease $2 \mathrm{mg} / \mathrm{ml}, 1 \mathrm{~h}$ & 0 & + & ND \\
Periodate $100 \mathrm{mM}, 1 \mathrm{~h}$ & 35 & - & $7 \cdot 7$ \\
\hline
\end{tabular}

ND, not done.

* Detected by negative staining with methylamine tungstate $2 \%$; percentage values represent the proportion of fimbriate cells when 100 cells were examined.

$\dagger$ Detected by Indian ink staining.

$\ddagger$ Mean widths determined by measuring the RRL in 10 cells in thin sections stained with ruthenium red.

$\S$ Fimbriate cells carried fewer fimbriae than did the fimbriate cells of the control.

\section{Discussion}

Adhesion by $\boldsymbol{B}$. fragilis strains shows tissue specificity, because adhesion to $\mathrm{BEC}$ was very low compared with that to the intestinal cells. This contrasts with work by Pruzzo et al. ${ }^{5,7}$ who found that strains which adhered well to an intestinal cell line also adhered well to BEC. Haemagglutination has been taken as an indication of the ability of an organism to adhere to eukaryotic cell membranes ${ }^{19}$ but we found no corre- lation between haemagglutination and adhesion to the intestinal cell line. However, strain A459, which gave the highest haemagglutination titre also adhered in highest numbers to the intestinal cells.

In the gut, epithelial cells are coated with a viscous layer of mucin which prevents colonisation by pathogenic bacteria. ${ }^{20}$ How?ver, mucin did not significantly decrease adhesion of , train A459 to intestinal cells. Therefore, in vivo this organism may either penetrate the mucin layer, adhere to exposed cells where the mucin layer is not continuous, or adhere to the mucin itself.

There has been controversy about which surface components mediate adhesion and haemagglutination in $B$. fragilis. It has variously been suggested that capsules, ${ }^{9}$ the electron-dense layer ${ }^{4}$ and fimbriae ${ }^{5}$ are responsible for adhesion. Some studies have also found a lack of any correlation between $B$. fragilis surface structures and their ability to adhere to erythrocytes $^{3,6-8}$ or intestinal cells. ${ }^{7}$ We found that the fimbriae of strain A459 did not mediate adhesion or haemagglutination because protease treatment removed the structures without affecting either property. However, periodate, which did not remove the fimbriae, was able totally to abolish haemagglutination and also to reduce adhesion to the intestinal cells. That these properties are sensitive to periodate and resistant to proteolytic enzymes is corroborated by Vel et $a .^{6}{ }^{6}$ Pruzzo et $a l^{7}$ found that both adhesion properties were sensitive to Pronase $E$ and to glucosidase. This contrasts with our experience of treating strain A459 with protease, but it agrees with the periodate inhibition we were able to demonstrate.

The fact that adhesion and haemagglutination are sensitive to periodate indicates that carbohydrate residues are important. Treatment with periodate resulted in the loss of the capsule but not the RRL, which may indicate that the capsule has a role in adhesion and haemagglutination. This was suggested by Pruzzo et $a l .{ }^{7}$ who proposed that both fimbriae and capsules may be involved in haemagglutination and adhesion. Onderdonk et al. ${ }^{2}$ found that pre-incubation with capsular material reduced the ability of $B$. fragilis to adhere to rat peritoneal mesothelium. However, Patrick et al. ${ }^{4}$ found that, for $B$. fragilis strains, the capsulate cells in the population lacked haemagglutinating ability, and only the non-capsulate subpopulation with an electron-dense surface layer agglutinated erythrocytes. It should also be noted that although the capsule may contribute to adhesion by $B$. fragilis A459, the non-capsulate strain, A334, was able to haemagglutinate and adhere to the cell line. Therefore, carbohydrate residues, such as those that form part of the LPS molecule, the RRL and cell surface glycoproteins could be involved but these possibilities remain to be investigated.

P. C. F. O. is in receipt of a Frederick Craven Moore Studentship from the University of Manchester. This work was supported by a consumables grant from the Smith-Kline Foundation. 


\section{References}

1. Lindberg AA, Berthold P, Nord CE, Weintraub A. Encapsulated strains of Bacteroides fragilis in clinical specimens. Med Microbiol Immunol (Berl) 1979; 167: 29-36.

2. Onderdonk AB, Moon NE, Kasper DL, Bartlett JG. Adherence of Bacteroides fragilis in vivo. Infect Immun 1978; 19: 10831087.

3. Shinjo T, Kiyoyama H. Fimbriae and hemagglutination in the Bacteroides fragilis group. Jpn J Vet Sci 1984; 46: 373-375.

4. Patrick S, Coffey A, Emmerson AM, Larkin MJ. The relationship between cell surface structure expression and haemagglutination in Bacteroides fragilis. FEMS Microbiol Lett $1988 ; 50: 67-71$.

5. Pruzzo C, Dainelli B, Ricchetti M. Piliated Bacteroides fragilis strains adhere to epithelial cells and are more sensitive to phagocytosis by human neutrophils than non-piliated strains. Infect Immun 1984; 43: 189-194.

6. Vel WAC, Namavar F, Verweij-van Vught AMJJ, Pubben ANB, MacLaren DM. Haemagglutination by the Bacteroides fragilis group. J Med Microbiol 1986; 21 : 105-107.

7. Pruzzo C, Guzmán CA, Dainelli B. Incidence of hemagglutination activity among pathogenic and non-pathogenic Bacteroides fragilis strains and role of capsule and pili in HA and adherence. FEMS Microbiol Lett 1989; 59: 113-118.

8. Oyston PCF, Handley PS. Surface structures, haemagglutination and cell surface hydrophobicity of Bacteroides fragilis strains. J Gen Microbiol 1990; 136: 941-948.

9. Riley TV, Mee BJ. Hemagglutination of Bacteroides fragilis. FEMS Microbiol Lett 1984; 25 : 229-232.

10. Duguid JP, Gillies RR. Fimbriae and adhesive properties in dysentery bacilli. J Pathol Bacteriol 1957; 74: 397-411.

11. Old DC. Inhibition of the interaction between fimbrial haemagglutinins and erythrocytes by D-mannose and other carbohydrates. J Gen Microbiol 1972; 71 : 149-157.
12. Loesche WJ, Hockett RN, Syed SA. The predominant cultivable flora of tooth surface plaque removed from institutionalized subjects. Arch Oral Biol 1972; 17: 1311-1325.

13. Augeron C, Laboisse CL. Emergence of permanently differentiated cell clones in a human colonic cancer cell line in culture after treatment with sodium butyrate. Cancer Res $1984 ; 44: 3961-3969$.

14. Vosbeck K, Huber U. An assay for measuring specific adhesion of an Escherichia coli strain to tissue culture cells. Eur J Clin Microbiol 1982; 1 : 22-28.

15. Harty DWS, Willcox MDP, Wyatt JE, Oyston PCF, Handley PS. The surface ultrastructure and adhesive properties of a fimbriate Streptococcus sanguis strain and six non-fimbriate mutants. Biofouling 1990; 2:75-86.

16. Handley PS, Harty, DWS, Wyatt JE, Brown CR, Doran JP, Gibbs ACC. A comparison of the adhesion, coaggregation and cell-surface hydrophobicity properties of fibrillar and fimbriate strains of Streptococcus salivarius. J Gen Microbiol 1987; 133: 3207-3217.

17. Handley PS, Tipler LS. An electron microscope survey of the surface structures and hydrophobicity of oral and non-oral species of the bacterial genus Bacteroides. Arch Oral Biol $1986 ; 31$ : 325-335.

18. Cruickshank $R$ (ed) Medical microbiology, 11th edn. Edinburgh, E and S Livingstone 1965: 651.

19. Duguid JP, Old DC. Adhesive properties of Enterobacteriaceae. In: Beachey EH (ed) Bacterial adherence (Receptors and recognition, vol 6, Series B). London, Chapman and Hall. 1980: 187-215.

20. Gibbons RJ. Review and discussion of role of mucus in mucosal defense. In: Strober W, Hanson LA, Sell KW (eds) Recent advances in mucosal immunity. New York, Raven Press. 1982: 343-351.

21. Handley PS, Carter PL, Fielding J. Streptococcus salivarius strains carry either fibrils or fimbriae on the cell surface. $J$ Bacteriol 1984; 157: 64-72. 